\title{
Proceeding
}

Supplementary Issue: Winter Conferences of Sports Science. Costa Blanca Sports Science Events, 22-23 March 2021. Alicante, Spain.

\section{New behavioral forms of sportsman students identification in university digital educational reality}

\author{
OLEG V. TIKHONOV ${ }^{1}$, MARIYA O. TIMOFEEVA², SERGEY A. POLEVOY ${ }^{3}$, NATALIA L. SOKOLOVA ${ }^{4}$, \\ RAISA I. PLATONOVA ${ }^{5}$, NATALIA A. ZAITSEVA ${ }^{6}$, YURIY G. VOLKOV7 \\ ${ }^{1}$ Department of Humanitarian Disciplines, Russian State University of Justice, Kazan, Russian Federation \\ ${ }^{2}$ Department of Human Anatomy, I.M. Sechenov First Moscow State Medical University of the Ministry of Health of the Russian \\ Federation (Sechenov University), Moscow, Russian Federation \\ ${ }^{3}$ Department of Management, Financial University under the Government of the Russian Federation (Financial University), \\ Moscow, Russian Federation \\ ${ }^{4}$ Institute of Foreign Languages, Peoples' Friendship University of Russia (RUDN University), Moscow, Russian Federation \\ ${ }^{5}$ Faculty of Road Construction, North-Eastern Federal University named after M.K. Ammosov, Yakutsk, Russian Federation \\ ${ }^{6}$ Department of Hospitality, Tourism and Sports Industry, Plekhanov Russian University of Economics, Moscow, Russian \\ Federation \\ ${ }^{7}$ Institute of Sociology and Regional Studies, Southern Federal University, Rostov-On-Don, Russian Federation
}

\begin{abstract}
The relevance of the research is due to a wide range of changes in the University educational reality caused by the influence of the Internet, computers, smartphones, mobile devices and modern gadgets on the behavioural forms of student identification. These processes are becoming a matter of particular concern to the public and University teachers. In this regard, this study reveals the features of the value priorities of the University digital educational reality, which modify the behavioural forms of student identification. In the course of pedagogical modelling, which is the leading research method, the phenomenon of new behavioural forms of student identification is identified as the leading idea of the University digital educational reality. This article reveals the key values of student identity identification in the University digital educational reality. The structure and content of new behavioural forms of student identification are established. Based on the research materials, the correction module of new behavioural forms of student identification in the University digital educational reality is justified. The module effectiveness is proved by the results of using new behavioural forms of student identification in the University educational process. The materials of the article are recommended to teachers, methodologists, organizers of the educational process and University students.

Keywords: Digital educational reality; Sportsman; Student identity identification; Value orientations; Nomadism; Electronic nomadism; Hypermobility; Electronic parkourism; Backpacking; Pedagogical modelling.

Cite this article as:

Tikhonov, O.V., Timofeeva, M.O., Polevoy, S.A., Sokolova, N.L., Platonova, R.I., Zaitseva, N.A., \& Volkov, Y.G. (2021). New behavioral forms of sportsman students identification in university digital educational reality. Journal of Human Sport and Exercise, 16(3proc), S1253-S1259. https://doi.org/10.14198/ihse.2021.16.Proc3.41

Corresponding author. Department of Humanitarian Disciplines, Russian State University of Justice, Kazan, Russian Federation.

E-mail: oleg.tihonov87@gmail.com

Abstract submitted to: Winter Conferences of Sports Science. Costa Blanca Sports Science Events, 22-23 March 2021. Alicante, Spain.

JOURNAL OF HUMAN SPORT \& EXERCISE ISSN 1988-5202.

(c) Faculty of Education. University of Alicante.

doi:10.14198/jhse.2021.16.Proc3.41
\end{abstract}




\section{INTRODUCTION}

The digital educational reality of the University is an open set of information systems designed to provide various tasks of the pedagogical process, filled with digital learning tools, the list of which is constantly growing and improving. Today - high - speed Internet; high - performance digital mobile devices smartphones, tablets; Web 2.0 tools-blogs, wikis, social networks; cloud services-Google, Office 365; a new generation of robotic devices and artificial intelligence (Asmolov, 2009; Attali, 2017; Bekarev, 2009; Gubanova, 2018; Deleuze \& Guattari, 2017; Crang, 2000; Russell \& Holmes, 1996; Tikhonov, 2013; Yakovleva, Seliverstova \& Grigorieva, 2017; Cherdymova et al., 2018). It is proved that all these devices constitute an instrumental platform of digital educational reality, open and accessible to every student. Ideally, a University graduate in this reality forms the whole set of creative qualities and abilities expected of him not only by the modern labour market, but also by scientific fields that solve the problems of creating robotics, artificial intelligence and other promising areas (Attali, 2017). In connection with these trends, the permanent interest of specialists and researchers in studying the features of the University digital educational reality remains. The problems of spreading new behavioural forms of identification of young people in this environment are of direct interest and particular concern to the public and University teachers. In this regard, this study attempts to substantiate the theoretical and methodological approach to determining the priority values of the University digital educational reality, which cause the spread of new behavioural forms of student identification. In the course of pedagogical modelling - the leading method of research, the implementation of new behavioural forms of personality in the University digital educational reality is justified as the leading idea of student identification. The article reveals the key values of student identity identification in the digital educational reality of the University. The structure and content of new behavioural forms of student identification are established. Based on the research materials, the correction module of new behavioural forms of student identification in the University digital educational reality is determined. The effectiveness of the module is proved by the results after using of the established behavioural forms of student identification in the University educational process.

\section{Literature review}

The famous psychologist E. Erikson (2006) identified the problem of identity identification in scientific discourse in the second half of the twentieth century.

E. Erickson is a representative of the American epigenetic school. E. Erikson's (2006) theoretical constructions are considered the most profound and reliable study of the regulatory function of identification in the formation of a person's ideas about him/herself and about the sequence of his/her behaviour in the surrounding reality. The special significance of substantiating new behavioural forms of student identification due to the University digital educational reality can be traced in a significant number of modern authors' studies (Asmolov, 2009; Attali, 2017; Bekarev, 2009; Gubanova, 2018; Deleuze \& Guattari, 2017; Zaitsev \& Nogina, 2018; Crang, 2000; Poleva, 2018; Tikhonov, 2013). The research notes that to date, the justification of new behavioural forms of student identification does not fully correspond to the stated imperatives of the University digital educational reality. The authors consider the question about the educational entity identification of the student to be open: is this phenomenon one of the conditions of the educational process, an integral element of the educational environment or the educational model of the University in which the main role is played not so much by the subject content as the resources of digital technology, initiating the emergence of new behavioural forms of identification. Proponents of digitalization of the University educational reality (Asmolov, 2009; Gubanova, 2018; Zaitsev \& Nogina, 2018; Kozyrkov, 2010; Russell \& Holmes, 1996; Tikhonov, 2013) prove its priority importance in updating the educational process. The authors consider the digital environment as an educational reality in which new behavioural forms of student 
identification are implemented. The established approaches to understanding the essence of the University digital educational reality and its significance in the implementation of new behavioural forms of student identification, in the works of A.G. Asmolov (2009), A.S. Gubanova (2018), N.J. Hancock et al. (2017), V.P. Kozyrkov (2010), N.N. Polevaya (2018), O.V. Tikhonov (2013), are justified as a theoretically and practically significant direction of modern research. In the course of the research, it was found that despite the active interest of researchers in the problem of student identification in the University digital educational reality, there is no complete scientific approach to its implementation in the presented works. So far, there are a significant number of theoretical and methodological problems that do not contribute to their productive solution. That is why the study of new behavioural forms of identification of a modern University student seems justified and timely for the educational theory and practice of the educational process.

\section{RESULTS AND DISCUSSION}

\section{Key values of student identity identification in university digital educational reality}

In this study, the key values of personal identification are considered as a necessary element of directed influence on the student, as a condition for self-identification of the student's $I$, as a necessary rule of influence on the personality, which determines the success of learning in the transitive conditions of digital educational reality. The structure and content of the key values of identification are the permanent values of selfidentification of the student's personality, socio-cultural value orientations and values that are the dominants of educational activities' content in the changed conditions.

\section{Permanent values of student self-identification}

- The authority of the teacher is a traditional condition for identification, however, in the digital educational reality, it retains the main load. In the course of the research, it was found that there is a close relationship between the teacher and the choice of value ideals by students of the study group, and the interest in the value ideals of the individual is directly proportional to the authority of the teacher;

- Emotions that influence the formation of incentives and motives for student identification. The study confirmed the assumption that the motive as a source of action is formed in the student's digital educational reality more dynamically and steadily under the influence of emotions of interest, joy, surprise, and novelty. In this aspect, the motivating role of rituals, traditions, and emotionally rich types of educational and extracurricular activities is noticeable in the conditions of higher education;

- Suggestion through the preliminary arousal of feelings in the student associated with his/her belonging to a certain group. In the scientific literature (Demidova, 2011), there is a well-known trend that states that a person is formed by a system of norms, values and rules with which he/she identifies him/herself. However, if the student is imbued with a sense of solidarity with a group of friends, he/she may choose a tactic of behaviour contrary to their values, but in accordance with the interests of this group;

- Overcoming the psychological barrier of alienation-the features of the manifestation are that in the case of socio-psychological tension in the relationship teacher-student, student - student, the feedback necessary for an effectively directed identification process is violated.

Social and cultural values of identification presented as:

1) The leading component of the personality structure, its interests, needs, motives, ideals, as well as memory, attention, thinking, abilities, imagination;

2) The result of assimilation of value - normative models dominating in the digital educational reality, the main ideas of personal development; 
3) Forecasting, orientation and coordination of socio-cultural values of student behaviour in a specific choice situation:

- Algorithm for forming an identification ideal;

- Structures of value orientations of identification accumulated in cognitive, emotional and behavioural components.

Values - the content's dominants of the identification process in the digital educational reality of the University. They serve as social regulators of the personality identification process. In the course of the research, the classification of values - dominants in the student's identification: vital, social, political, moral, religious, and aesthetic-was established and tested in the educational process of the University. The typology of student identification in the digital educational reality of the University is determined and revealed based on dominant values:

- Identification with the traditional values of the University's information space;

- Identification with the established system and standards of values of digital educational reality;

- Identification with your needs, motivated by the value of digital technologies;

- Identification with its new behavioural forms in the digital educational reality of the University.

\section{New behavioural forms of student personality identification}

According to the results of the research, new behavioural forms of identification - electronic nomadism, hypermobility, parkour, and backpacking-have become widespread in the digital educational reality of the University.

\section{Electronic nomadism}

Over the past decades of the XX1 century, the paradigm of the University's educational system has changed significantly. The intensification of the digital educational reality has brought its extraordinary results. The student's personality, for whose sake all modernizations are carried out, has been transformed in such a way that digital technologies have become a continuation of his/her corporeality and behaviour management (Gubanova, 2018). Digital technologies determine the student's behaviour through the constantly surrounding digital environment, a kind of digital belt that controls physical activity, thinking, cognitive and creative activities, and communication. The student does not realize the appearance of dependence on electronic means, since all the main time is associated with digital technologies and such interaction is perceived as the norm. The student's passion for digital technologies creates the need to conquer new virtual spaces (levels), in which he/she performs actions that give impetus to the next victories. This trend in the scientific literature (Yakovleva, Seliverstova \& Grigorieva, 2017) is designated by the term nomadism (electronic nomadism). The characteristic features of the modern student - nomadist: lack of affection, his/her life has no point of support in the form of home, family, children, the constant cravings, the whole way of life is identical to a virtual environment is moving and flowing (Deleuze \& Guattari, 2017). In the course of the research, it was found that the lack of life principles and attachments, constant roaming on networks give rise to complexes of uncertainty and loneliness in the student, lack of understanding of real situations. All this complicates the processes of identification, communication, interpersonal and business cooperation, and creates barriers to the prospective growth and development of the student.

\section{Hypermobility}

Interdisciplinary discourse of new behavioural forms of student identification in the digital educational reality of the University speaks about the fundamental nature of changes in student behaviour and the variety of forms of its manifestation. Hypermobility becomes one of the most important characteristics of student identification. Transience, mosaic and Antinomian of information processes are characteristic features of the 
digital reality of the University, which negatively affects the student's thinking. Due to these specific circumstances, thinking is characterized by a lack of clarity and logical consistency, and the behaviour of the student does not correspond to generally accept ethical norms and rules in society. Daily change of information flows, disrupts the concentration of attention, develops a syndrome of absent-mindedness in perception and discrete nature of memory operation. In addition, the information received is not subjected to careful study, analysis, or comparison. Not becoming knowledge, it usually comes up spontaneously, on any occasion, and is just as quickly erased from memory. As a result, the student forms a reflex of rejection of the ability to act humanly, be responsible and informed (Yakovleva, Seliverstova \& Grigorieva, 2017).

\section{Electronic parkour (From French parcours du combattant)}

The art of moving and overcoming obstacles. In the course of the research, the trends of permanent visits to randomly selected electronic sites and applications of electronic devices, during which the student solves several tasks, were established. In the digital educational environment of the University, when a student opens several programs and documents on his/her electronic device, begins to edit or upload them, transfer information from one medium to another, solve problems of rational movement between open information resources in a state of multitasking, he/she reproduces actions similar to parkour as a new behavioural form of identity identification.

\section{Backpacking (English - backpack)}

In the course of the study, backpacking is justified as a new behavioural form of identification of the student's personality, the scale of which is geographically (spatially) expanding (Abdulkhairov \& Abdulkhairova, 2016). The most active participants in this form of identification (back-packers) are students who implement their tourist preferences using digital technologies, mainly through specialized resources on the Internet. Traveling around the world, the main goal of a backpacker is primarily to expand their own knowledge and impressions of new places, culture, customs and traditions of the peoples who inhabit these places, and to establish crosscultural interaction with representatives of these peoples. The results of the research confirm the assumption that backpacking, as a behavioural pattern of a modern student, is a positive form of identification that actualizes the rootedness of the ideals and values of cultural interaction of young people, expanding the boundaries of the digital educational reality of the University.

\section{Correction module of new behavioural forms of student personality identification in the digital educational reality of the university}

The correction module in this study is a software package that provides cognitive, emotional and behavioural levels of step-by-step correction of new forms of student identification in the digital educational reality of the University.

At the cognitive level, students' knowledge about the structure and content of identification values and new behavioural forms of identification is refined, generalized and systematized. The mechanisms of correcting the values of identification's new behavioural forms in the digital educational reality are determined. At the emotional level, the degree of personal attitude to the values of identification, to the peculiarities of electronic nomadism, personal reflection and emotional empathy to corrective actions in relation to new behavioural forms of identification is corrected. At the behavioural level, programs, action plans, specific techniques are adjusted, and a comparative analysis of traditional and new forms of identification is carried out, ensuring their effective use in the digital educational reality of the University.

The experimental module is implemented in the digital educational reality of the University using a simple and practical set of corrective measures: 
- Self-education. Independent study by students of information about new behavioural forms of identification in the digital educational reality of the University: systematization, study of special literature, selection of information from various Internet sources: blogs, manuals, trainings, and webinars.

- Establishing interaction with fellow students, teachers, Tutors, curators in order to conduct continuous monitoring studies of a specific behavioural form of identification.

- Implementation of mentworking (studying models of successful identification by students at their own University and innovative experience of other universities). Creative interaction with the curator, tutor.

- Performing special tasks: background trainings; master classes focused on the development of personal qualities, values, attitudes, motives and needs, modern traditions, ideals of universal values; mechanisms for correcting bad habits.

- Case studies: study of specific situations with the results of optimal solutions.

- Personal reflection in the process of activity.

- Forecasting new behavioural forms of identification when solving educational tasks in the digital educational reality of the University.

\section{CONCLUSION}

The research confirms the theoretical and practical significance of implementing new behavioural forms of student identification in the digital educational reality of the University. These processes are caused by an intensive rethinking of traditional values, value orientations of student personality identification in the educational process of the University and the introduction of new behavioural forms of identification such as electronic nomadism, hypermobility, electronic parkourism, backpacking in the digital educational reality. These strategies put the modern student in a strict framework of organizing and choosing their own identification strategies in the digital educational reality of the University. In this regard, the study substantiates the conceptual provisions of the theoretical and methodological approach to determining the value priorities of new behavioural forms of student identification in the digital educational reality of the University:

1) The key values of student personality identification in the digital educational reality of the University are revealed;

2) The authors have established the structure and content of new behavioural forms of student personality identification;

3) Based on the research materials, the correction module of new behavioural forms of student personality identification in the digital educational reality of the University is justified.

The article materials focused on the continuation of studies in the practical application of the structure and content of new behavioural forms' value model of identification in University digital educational reality and in the academic activities of teachers, trainers and students.

\section{REFERENCES}

Abdulkhairov, A.Z. \& Abdulkhairova, E.M. (2016). Crimean tourism. Service in Russia and abroad, 10(9), 41-48.

Asmolov, A.G. (2009). From We-media to I-media: identity transforming in the virtual world. Questions of psychology, 3, 3-15. https://doi.org/10.11621/pir.2009.0006 
Attali, Zh. (2017). On the threshold of a new Millennium. In Russian. Retrieved from: http://modernlib.ru/books/attali_zhak/na_poroge_novogo_tisyacheletiya/read (accessed: 15. 09. 2017).

Bekarev, A.M. (2009). Modern nomadism: problems of organization and disorganization. Bulletin of the University of Nizhny Novgorod named after Lobachevski. Ser. Social Sciences, 4(6), 23 - 29.

Cherdymova, E.I., Afanasjeva, S.A., Parkhomenko, A.G., Ponyavina, M.B., Yulova, E.S., Nesmeianova, I.A. \& Skutelnik, O.A. (2018). Student ecological consciousness as determining component of ecological-oriented activity. EurAsian Journal of BioSciences, 12(2), 167-174.

Crang, M. (2000). Public space, urban space and electronic space: would the real city please stand up? Urban Studies, 37(2), 301-317. https://doi.org/10.1080/0042098002203

Deleuze, J. \& Guattari, F. (2017). A treatise on nomadology. In Russian. Retrieved from: http://www.situation.ru/app/_art_1022.htm (date of request: 15.09.2017).

Demidova, L.T. (2011). Socio-cultural values of the content of humanitarian disciplines - factor of socialization of a University student's personality. Kazan: Kazan state energy university publishing house.

Erikson, E. (2006). Identity: youth and crisis. Moscow: Flinta.

Gubanova, A.S. (2018). Internet technologies as an extension of the human body: a socio-philosophical analysis. Saratov university news. New. ser. Philosophy. Psychology. Pedagogy, 18(3), 252-255. https://doi.org/10.18500/1819-7671-2018-18-3-252-255

Hancock, N.J., Joux, N.R., Wingreen, S.C., Kemp, J.T. \& Helton, W.S. (2017). Positive post-disaster images: A daydream machine? British Journal of Psychology, 108(3), 528-543. https://doi.org/10.1111/bjop.12213

Kozyrkov, V.P. (2010). Modern information Luddites. Actual problems of social communication: materials of the first international scientific and practical conference. Nizhny Novgorod: Nizhny Novgorod state technical University named after P. E. Alekseev.

Polevaya, N.N. (2018). From identification to identity. Psychological research, 11(58), 1-12.

Russell, G. \& Holmes, D. (1996). Electronic nomads? Implications of trends in adolescents' use of communication and information technology. Australasian Journal of Educational Technology, 12(2), 133-143. https://doi.org/10.14742/ajet.2042

Tikhonov, O.V. (2013). Transformation of the phenomenon of identity in the space of the Internet: PhD Thesis. Kazan.

Yakovleva, E.L., Seliverstova, N.S. \& Grigorieva, O.V. (2017). The concept of e-nomad: the risks of the development of the digital economy. Current problems of Economics and law, 11(4), 226-241. https://doi.org/10.21202/1993-047X.11.2017.4.226-241

Zaitsev, V.S. \& Nogina, A.A. (2018). Self-identification of future teachers of professional training: Genesis, structure, conditions. Bulletin of Chelyabinsk state pedagogical University, 6, 111-123. Chelyabinsk.

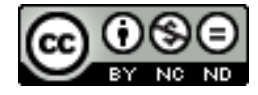

This work is licensed under a Attribution-NonCommercial-NoDerivatives 4.0 International (CC BY-NC-ND 4.0). 